\title{
Labrenzia callyspongiae sp. nov., Isolated from Marine Sponge Callyspongia elegans in Jeju Island's
}

\author{
So Hyun Park ${ }^{1}$, Ji Young, $\mathrm{Kim}^{2 *}$, and Moon Soo, $\mathrm{Heo}^{1 *}$ \\ ${ }^{1}$ Department of Aquatic Life Medicine, Jeju National University, Jeju 63243, Republic of Korea \\ ${ }^{2}$ Research institute for Basic Science, Jeju National University, Jeju 63243, Republic of Korea
}

\author{
Received: December 5, 2018 \\ Revised: October 23, 2019 \\ Accepted: October 23, 2019 \\ First published online: \\ November 1, 2019 \\ ${ }^{*}$ Corresponding authors \\ M.S.H. \\ Phone: +82-64-754-3473 \\ Fax: +82-64-756-3493 \\ E-mail: msheo@jejunu.ac.kr \\ J.Y.K. \\ Phone: +82-10-7253-2563 \\ Fax: +82-64-756-3493 \\ E-mail: jym1006@jejunu.ac.kr \\ S upplementary data for this \\ paper are available on-line only at \\ http://jmb.or.kr. \\ pISSN 1017-7825, eISSN 1738-8872 \\ Copyright(C) 2019 by \\ The Korean Society for Microbiology \\ and Biotechnology
}

\begin{abstract}
A Gram-staining-negative, aerobic, light brown pigment bacterium, designated strain CE80 was isolated from marine sponge Callyspongia elegans in Jeju Island, Republic of Korea. Strain $\mathrm{CE} 80^{\mathrm{T}}$ grew optimally at $25^{\circ} \mathrm{C}$, in the range of $\mathrm{pH} 5.0-11.0$ (optimum 7.0-8.0), and with $1.0-5.0 \%$ $\mathrm{NaCl}$ (optimum 1-3\% (w/v)). Phylogenetic analysis based on the 16S rRNA gene sequence showed that strain $\mathrm{CE} 80^{\mathrm{T}}$ belonged to the genus Labrenzia and was closely related to L. suaedae ${\mathrm{YC} 6927^{\mathrm{T}}(98.3 \%) \text {, L. alexandrii DFL-11 }}^{\mathrm{T}}(96.6 \%)$, L. aggregata IAM $12614^{\mathrm{T}}$ (96.6\%) L. marina mano $18^{\mathrm{T}}(96.5 \%)$ and L. alba CECT $5094^{\mathrm{T}}(96.2 \%)$. The major fatty acids of strain CE $80^{\mathrm{T}}$ were $C_{18: 1} \omega 7 c$, and summed feature. The polar lipids were diphosphatidylglycerol, phosphatidylcholine, phosphatidylethanolamine, phosphatidylglycerol, phosphatidylmonomethylethanolamin, one unidentified aminolipid, one phospholipid and four unidentified lipids. The DNA G+C content of strain $\mathrm{CE} 80^{\mathrm{T}}$ was $55.9 \mathrm{~mol} \%$. The major respiratory quinone was Q-10. DNA-DNA relatedness between strain CE80 ${ }^{\mathrm{T}}$ and L. suaedae $\mathrm{YC} 6927^{\mathrm{T}}$ was $56.1 \pm 2.8 \%$. On the basis of physiological and biochemical characterization and phylogenetic and chemotaxonomic analysis, strain $\mathrm{CE} 80^{\mathrm{T}}$ represents a novel species of the Labrenzia, for which the name Labrenzia callyspongiae sp. nov., is proposed. The type strain is CE80 ${ }^{\mathrm{T}}\left(=\mathrm{KCTC} 42849^{\mathrm{T}}\right.$ $=\mathrm{JCM} 31309^{\mathrm{T}}$ ).
\end{abstract}

Keywords: Labrenzia, marine sponge, novel species, $16 \mathrm{~S}$ rRNA

\section{Introduction}

The genus Labrenzia, established by Biebl et al. [1], belongs to the class Alphaproteobacteria and the family Rhodobacteraceae. At the time of writing, six species of the genus Labrenzia including the recently described species L. suaedae [2] and L. salina [3] have been identified, which were isolated from marine habitats and tidal flats, as dinoflagellates and halophytes, respectively. The members of genus Labrenzia are gram-negative, aerobic, and most species show the presence of glycolipid sulphoquinovosuldiacylglyceride (SQDG). Some species also synthesize bacteriochlorophyll $a$ (BChl a). Previously, the genus Agrobacterium was reported by Stapp \& Knosel [4] and Ruger \& Hofle [5]; Agrobacterium aggregatum was described by Ahrens [6], and later the taxonomic position of the marine subdivision Agrobacterium was reassessed resulting in two species of the genus
Agrobacterium getting transferred to the new genus Stappia as Stappia aggregata and Stappia stellulata [7] and finally reclassified as Labrenzia aggregata by Biebl et al. [1]. Stappia alba described by Pujalte et al. [8] and Stappia marina described by Kim et al. [9] were reclassified as Labrenzia alba and Labrenzia marina, respectively [1]. In the present study we determined the exact taxonomic position of strain ce80T by using a polyphasic characterization that included the determination of phenotypic, physiological and 16S rRNA gene sequence analysis, chemotaxonomic properties, and DNA-DNA hybridization.

\section{Materials and Methods}

\section{Isolation}

Strain $\mathrm{CE} 80^{\mathrm{T}}$ was isolated from marine sponge Callyspongia elegans collected at Jeju Island. To isolate marine bacteria, the 
sponge sample of homogenized core tissue was 10-fold diluted with sterilized $0.85 \%(\mathrm{w} / \mathrm{v}) \mathrm{NaCl}$ solution. Each dilution was inoculated onto marine agar 2216 (MA; Difco, USA) and incubated at $25^{\circ} \mathrm{C}$ for 7 days under aerobic conditions. The isolate was purified by repeated subculture and stored at $-80^{\circ} \mathrm{C}$ as a suspension marine broth (MB; Difco, USA) containing 20\% (v/v) glycerol. The type strains of the most closely related species, L. suaedae KACC 13772 and L. aggregate KACC 15203 ${ }^{\mathrm{T}}$ were obtained from the Korean Agricultural Culture Collection (KACC); L. marina KCTC $12288^{\mathrm{T}}$ was obtained from the Korean Collection for Type Cultures (KCTC); L. alba DSM $18320^{\mathrm{T}}$ and L. alexandrii DSM $17067^{\mathrm{T}}$ were obtained from the Deutsche Sammlung von Mikroorganismenund Zellkulturen (DSM).

\section{S rRNA Gene Sequencing and Phylogenetic Analyses}

For 16S rRNA gene [10] sequencing, genomic DNA [11] was extracted from strain $\mathrm{CE} 80^{\mathrm{T}}$ and amplified by PCR with two universal primers, 27F (5'-AGAGTTTGATCCTGGCTCAG-3') and 1522R (5'-AAGGAGGTGATCCAGCCGCA-3'). The amplified PCR product was cloned using the TOPO cloning kit (Invitrogen) and sequence analysis was requested from Genotech (Korea). Full sequence of the 16S rRNA gene was assembled using SeqMan software (DNASTAR) and we obtained the sequences for related taxa from GenBank and the EzTaxon-e server (www.ezbiocloud.net) [12]. The 16S rRNA gene sequences of strain $\mathrm{CE} 80^{\mathrm{T}}$ and related type strains were aligned by using CLUSTAL_X [13], while the BioEdit program [14] was used to edit gaps. Phylogenetic analysis was performed using the MEGA 6.0 software package [15] and phylogenetic trees were reconstructed based on the maximumlikelihood [16], maximum-parsimony [17] and neighbor-joining [18] methods through bootstrap analysis based on 1000 replicates [19]. Evolutionary distances were calculated using Jukes-Cantor model. The whole genome sequence of CE80T was performed by Macrogen (Republic of Korea) sequencing service. The sequencing library was prepared using TruSeq DNA PCR Fee kit according to the manufacturer's instructions. The genome sequence data were produced using the Illumina Hiseq 4000 platform and assembled de novo with SPAdes version 3.13.0 [20]. Also, the average nucleotide identity (ANI) was calculated using an ANI calculator (www. Ezbiocloud.net/tool/ani) [21].

\section{Morphology and Physiological, and Biochemical Characterization}

The cell morphology of cell was observed by light microscopy (Nikon, Japan), scanning electron microscopy and transmission electron microscopy (SUPRA66VP, ZEISS). Gliding motility was determined according to Schaal [22]. Gram staining was conducted using the Gram Stain Kit (BD Science, USA) according to the manufacturer's instructions. Growth of strain $\mathrm{CE} 80^{\mathrm{T}}$ was evaluated on MA at different temperatures $\left(5,10,15,20^{\circ} \mathrm{C}, 25^{\circ} \mathrm{C}, 30^{\circ} \mathrm{C}, 35^{\circ} \mathrm{C}\right.$, $40^{\circ} \mathrm{C}, 45^{\circ} \mathrm{C}$, and $50^{\circ} \mathrm{C}$ ) for 5 days. The $\mathrm{pH}$ range for growth was determined in marine broth adjusted to $\mathrm{pH} 4.0-11.0(0.5 \mathrm{pH}$ unit intervals) using citric acid/sodium citrate buffer, $\mathrm{KH}_{2} \mathrm{PO}_{4} / \mathrm{K}_{2} \mathrm{HPO}_{4}$ and $\mathrm{NaHCO}_{2} / \mathrm{Na}_{2} \mathrm{CO}_{2}$ as buffering systems. Tolerance to $\mathrm{NaCl}$ was tested in synthetic marine ZoBell medium (5 g Bacto peptone, $1 \mathrm{~g}$ yeast extract, $0.1 \mathrm{~g}$ ferric citrate, $15 \mathrm{~g}$ agar in $1 \mathrm{~L}$ distilled water) (ZoBell, 1941) supplemented with various $\mathrm{NaCl}$ concentrations (0$10 \%, \mathrm{w} / \mathrm{v}$, intervals $1 \%$ ). Anaerobic growth was determined on $\mathrm{MA}$ at $25^{\circ} \mathrm{C}$ for 2 weeks under anaerobic condition (in an anaerobic jar with the Anaerobic Pack (Oxid)). Catalase and oxidase activity were tested by bubble formation in $3 \%$ hydrogen peroxide $\left(\mathrm{H}_{2} \mathrm{O}_{2}\right)$ solution and using $1 \%(\mathrm{w} / \mathrm{v})$ tetramethyl-P-phenylenediamine. Hydrolysis tests were performed using MA containing starch, casein, Tween 20,40,60, 80, cellulose and DNase, respectively [23]. The enzyme activities and biochemical characteristics were tested by using API ZYM and API 20 NE kits (bioMerieux) according to the manufacturer's instructions. These tests were performed at $25^{\circ} \mathrm{C}$ for 5 days.

\section{Chemotaxonomy}

For cellular fatty acid analysis, strain $\mathrm{CE} 80^{\mathrm{T}}$ and one reference strain were harvested from MA after cultivation at $25^{\circ} \mathrm{C}$ for 5 days. Saponification, methylation and extraction of cellular fatty acids were performed by gas chromatography according to the protocol for the Sherlock Microbial Identification System (MIDI; version 6.1) and the TSBA6 database [24].

For analysis of the polar lipids, cell mass was harvested after incubation at $25^{\circ} \mathrm{C}$ for 5 days in MA and freeze-dried. Polar lipid analysis of strain $\mathrm{CE} 80^{\mathrm{T}}$ was carried out using two-dimensional TLC as described by Minnikin et al. [25]. The polar lipids were extracted and separated using chloroform/methanol/water (65:25:4, by volume) for the first dimension and chloroform/ methanol/acetic acid/water (80:12:15:4, by volume) for the second dimension [25], while molybdophosphoric acid (for total lipids), ninhydrin (for lipids containing free amino groups), molybdenum blue (for phosphorus-containing lipids) and $\alpha$-naphthol (for glycolipids) were used for the detection reagents [26].

Analysis of the respiratory quinones was performed by reversedphase high-performance liquid chromatography [25].

\section{Genomic Analyses}

DNA G+C content of strain CE80 ${ }^{\mathrm{T}}$ was detected by using HPLC analysis [27] at the Korean Culture Center of Microorganisms (KCCM). DNA-DNA hybridization of strain CE $80^{\mathrm{T}}$ and type strain L. suaedae was performed with photobiotin-labelled DNA probes and microplate hybridization method by Ezaki et al. [28]. The experiment was with done five replications and the mean values were calculated for DNA-DNA relatedness.

To detect the presence of a gene related to production of bacteriochlorophyll a (BChl a), the pufLM gene was amplified using specific primers as described by Kim et al. [9].

\section{Results and Discussion}

Cells of strain $\mathrm{CE} 80^{\mathrm{T}}$ were gram-negative, aerobic, bright brown rods $(0.56-0.74 \mu \mathrm{m} \times 1.5-2.7 \mu \mathrm{m})$ and exhibited gliding 
motility. The growth occurred at $10-37^{\circ} \mathrm{C}$ (optimum $25^{\circ} \mathrm{C}$ ) and $\mathrm{pH}$ 5.0-11.0 (optimum 7.5). The range of $\mathrm{NaCl}$ for growth was $1-5 \%(\mathrm{w} / \mathrm{v})$ (optimum $1-3 \%$ ). The detailed results of the morphological, physiological and biochemical characteristics are described and compared with type

Table 1. Comparisons of phenotype characteristics of strain $\mathrm{CE} 80^{\mathrm{T}}$ and closely related type strains of the genus Labrenzia.

\begin{tabular}{|c|c|c|c|c|c|c|}
\hline Characteristic & 1 & 2 & 3 & 4 & 5 & 6 \\
\hline \multicolumn{7}{|l|}{ Growth at/with } \\
\hline $0 \% \mathrm{NaCl}$ & - & + & - & - & + & - \\
\hline $10 \% \mathrm{NaCl}$ & - & - & - & - & + & - \\
\hline \multicolumn{7}{|l|}{ Hydrolysis of : } \\
\hline DNA & + & - & + & + & - & - \\
\hline Aesculin & - & + & + & + & + & + \\
\hline \multicolumn{7}{|l|}{ API ZYM } \\
\hline Cystine arylamidase & + & + & + & - & - & + \\
\hline$\alpha$-chymotrypsin & - & + & - & - & - & + \\
\hline$\beta$-glucuronidase & - & + & - & + & - & - \\
\hline$\alpha$-glucosidase & - & + & + & + & - & + \\
\hline$\beta$-glucosidase & - & + & - & - & - & - \\
\hline $\mathrm{N}$-acetyl-b-glucosamidase & - & + & + & + & - & - \\
\hline$\alpha$-mannosidase & - & + & - & + & - & - \\
\hline$\alpha$-fucosidase & - & + & - & - & - & - \\
\hline \multicolumn{7}{|l|}{ API 20NE } \\
\hline D-Glucose & - & + & - & - & - & + \\
\hline D-Arabinose & - & + & - & - & - & + \\
\hline D-mannose & - & + & - & - & - & + \\
\hline D-Mannitol & - & + & - & - & - & + \\
\hline $\mathrm{N}$-acetyl-D-glucosamine & - & + & - & - & - & + \\
\hline Gluconate & - & + & - & - & - & + \\
\hline malate & - & + & - & - & - & + \\
\hline Citrate & - & + & - & - & - & + \\
\hline Presence of pufLM genes & - & + & + & ND & - & + \\
\hline presence of SQDG & - & - & + & $+^{*}$ & $+^{*}$ & $+^{*}$ \\
\hline DNA G $+C$ content & 55.9 & $58.5^{*}$ & $60^{*}$ & ND & $59^{*}$ & $56^{*}$ \\
\hline
\end{tabular}

Strains: 1, Strain CE $80^{\mathrm{T}}$ (this study); 2, L. suaedae KACC $13772^{\mathrm{T}}$; 3, L. marina KCTC12288 ${ }^{\mathrm{T}} ; 4$, L. alba DSM $18320^{\mathrm{T}} ; 5$, L. aggregata KACC $15203^{\mathrm{T}} ; 6$, L. alexandrii DSM $17067^{\mathrm{T}}$. All strains are positive for motility, oxidase, catalase, reduction of nitrates to nitrites, hydrolysis of gelatin, assimilation of $\beta$-galactosidase, activities of alkaline phosphatase, esterase (C4), esterase lipase (C8), leucine arylamidase, valine arylamidase, cysteine arylamidase, trypsin, acid phosphatase, naphtol-AS-BI-phosphohydrolase and $\alpha$-galactosidase. All strains are negative for: hydrolysis of starch, casein, Tween 20,60, cellulose, indole production, glucose fermentation; arginine dihydrolase, assimilation of Dmaltose, caprate, adipate, phenylacetate; lipase (C14) and Naphthol-AS-BI- $\beta$ Dglucuronide activities.

*Data taken from Bibi et al. (2014). strains Labrenzia suaedae as listed in Table 1.

The almost full-length 16S rRNA gene sequence of strain CE80 ${ }^{\mathrm{T}}$ (1,384 bp) was obtained. Based on phylogenetic analysis, strain $\mathrm{CE} 80^{\mathrm{T}}$ was shown to be most closely related to members of genus Labrenzia exhibiting highest 16S rRNA gene sequence similarity to L. suaedae YC6927 ${ }^{\mathrm{T}}(98.3 \%)$, L. alexandrii DFL-11 ${ }^{\mathrm{T}}(96.6 \%)$, L. aggregata IAM $12614^{\mathrm{T}}(96.6 \%)$ L. marina mano $18^{\mathrm{T}}$ (96.5\%) and L. alba CECT $5094^{\mathrm{T}}(96.2 \%)$. A phylogenetic tree based on the neighbor-joining algorithm showed that strain $\mathrm{CE} 80^{\mathrm{T}}$ formed a phylogenetic lineage distinct from but related closely to type strain Labrenzia suaedae YC6927 ${ }^{\mathrm{T}}$ with $81 \%$ bootstrap support (Fig. 1).

The draft assembled genome size of strain $\mathrm{CE} 80^{\mathrm{T}}$ was $4,737,804 \mathrm{bp}$, contained seven contigs and an N50 length of 2,393,935 bp. The ANI value between strain CE80 ${ }^{\mathrm{T}}$ and type strain L. suaedae $\mathrm{YC} 6927^{\mathrm{T}}$ was $83.7 \%$, which was lower than the standard cut-off of 95-96\% [29] for species identity.

The presence of the pufLM genes can show ability to synthesize the photosynthetic reaction center. To confirm the presence pufLM genes of strain $C E 80^{\mathrm{T}}$, we used a specific primer and the gene was not found. This result shows that the photosynthetic reaction center may not be functional in this strain, which is found in other reported

Table 2. Cellular fatty acid compositions (\%) of strain CE80 and closely related type strains of the genus Labrenzia.

\begin{tabular}{lcccccc}
\hline \multicolumn{1}{c}{ Fatty acid } & $\mathbf{1}$ & $\mathbf{2}$ & $\mathbf{3}$ & $\mathbf{4}$ & $\mathbf{5}$ & $\mathbf{6}$ \\
\hline Saturated & & & & & & \\
$\mathrm{C}_{10: 0}$ & $\operatorname{tr}$ & 2.1 & $\operatorname{tr}$ & $\operatorname{tr}$ & $\operatorname{tr}$ & $\operatorname{tr}$ \\
$\mathrm{C}_{16: 0}$ & $\operatorname{tr}$ & 2.1 & $\operatorname{tr}$ & $\operatorname{tr}$ & $\operatorname{tr}$ & $\operatorname{tr}$ \\
$\mathrm{C}_{18: 0}$ & 4.7 & $\operatorname{tr}$ & 6.2 & 6.4 & 3.5 & 3.2 \\
Unsaturated & & & & & & \\
$\quad \mathrm{C}_{18: 1} \omega 7 \mathrm{c}$ & 66.8 & 66.4 & 55.9 & 70.5 & 69.9 & 67.7 \\
$\mathrm{C}_{20: 1} \omega 7 \mathrm{c}$ & 2.6 & - & 4.7 & 7.5 & 7.4 & 14.3 \\
$\begin{array}{l}11-m e t h y l ~ \mathrm{C}_{18: 1} \omega 7 \mathrm{c} \\
\quad\end{array}$ & 4.5 & 3.2 & 9.9 & 6.8 & 8.0 & 5.7 \\
$\quad$ Cyclo $\mathrm{C}_{19: 0} \omega 8 \mathrm{c}$ & - & - & 6.2 & - & - & - \\
Hydroxy & & & & & & \\
$\quad \mathrm{C}_{18: 0} 3-\mathrm{OH}$ & 2.3 & 6.7 & 2.0 & $\operatorname{tr}$ & $\operatorname{tr}$ & $\operatorname{tr}$ \\
Summed features & & & & & & \\
2 & 10.3 & 8.8 & 3.1 & 3.7 & 4.1 & 3.7 \\
3 & $\operatorname{tr}$ & $\operatorname{tr}$ & 8.5 & - & $\operatorname{tr}$ & $\operatorname{tr}$ \\
\hline
\end{tabular}

Strains: 1, strain CE $80^{\mathrm{T}}$ (this study); 2, L.suaedae KACC $13772^{\mathrm{T}}$; 3, L. marina KCTC12288 $;$ 4, L. alba DSM $18320^{\mathrm{T}} ; 5$, L. aggregata KACC $15203^{\mathrm{T}} ;$ 6, L. alexandrii DSM $17067^{\mathrm{T}}$. All data were obtained from this study. Values are percentages of total fatty acids (less than $2 \%$ are not show); tr, Traces $(<2.0 \%) ;-$, not detected. *Summed features represent groups of two or three fatty acids that cannot be separated by gas chromatography with the MIDI system. Summed features 2 comprised $\mathrm{C}_{14: 0} 3-\mathrm{OH}$ and/or iso- $\mathrm{C}_{16: 1} \mathrm{I} ; 3, \mathrm{C}_{16: 1} \omega 7 \mathrm{c}$ and/or iso- $\mathrm{C}_{15: 0} 2-\mathrm{OH}$. 
members such as L. alexandrii, L. marina, L. suaedae, and L. salina $[1,2,3,9]$.

The cellular fatty acids ( $>2 \%$ of the total fatty acids) of strain $\mathrm{CE} 80^{\mathrm{T}}$ were $\mathrm{C}_{18: 1} \omega 7 c(66.7 \%)$, summed feature $2\left(\mathrm{C}_{14: 0}\right.$ $3-\mathrm{OH} /$ iso- $\mathrm{C}_{16: 1}$ I) $(10.2 \%), \mathrm{C}_{18: 0}(4.7 \%)$ 11-methyl $\mathrm{C}_{18: 1} \omega 7 c$ $(4.4 \%), \mathrm{C}_{20: 1} \omega 7 c(2.6 \%)$, and $\mathrm{C}_{18: 0} 3-\mathrm{OH}(2.2 \%)$ (Table 2). The predominant fatty acids of strain $\mathrm{CE} 80^{\mathrm{T}}$ and L. suaedae were $\mathrm{C}_{18: 1} \omega 7 c$ and summed features 2 . The fatty acids $\mathrm{C}_{18: 1} \omega 9 c$ and $C_{20: 1} \omega 7 c$ were present in strain $C E 80^{\mathrm{T}}$, but absent in L. suaedae. The predominant respiratory quinone of strain
CE80 ${ }^{\mathrm{T}}$ was ubiquinone $10(\mathrm{Q}-10)$, which was in line with all members of the genus Labrenzia.

The predominant polar lipids of the strain $\mathrm{CE} 80^{\mathrm{T}}$ were diphosphatidylglycerol (DPG), phosphatidylcholine (PC), phosphatidylethanolamine (PE), phosphatidylglycerol (PG), phosphatidylmonomethylethanolamin (PMME), one unknown aminolipid, one unknown phospholipid and four unknown lipids. These polar lipids profiles were the most similar pattern observed in all members of the genus Labrenzia. The presence of sulphoquinovosyldiacylglyceride

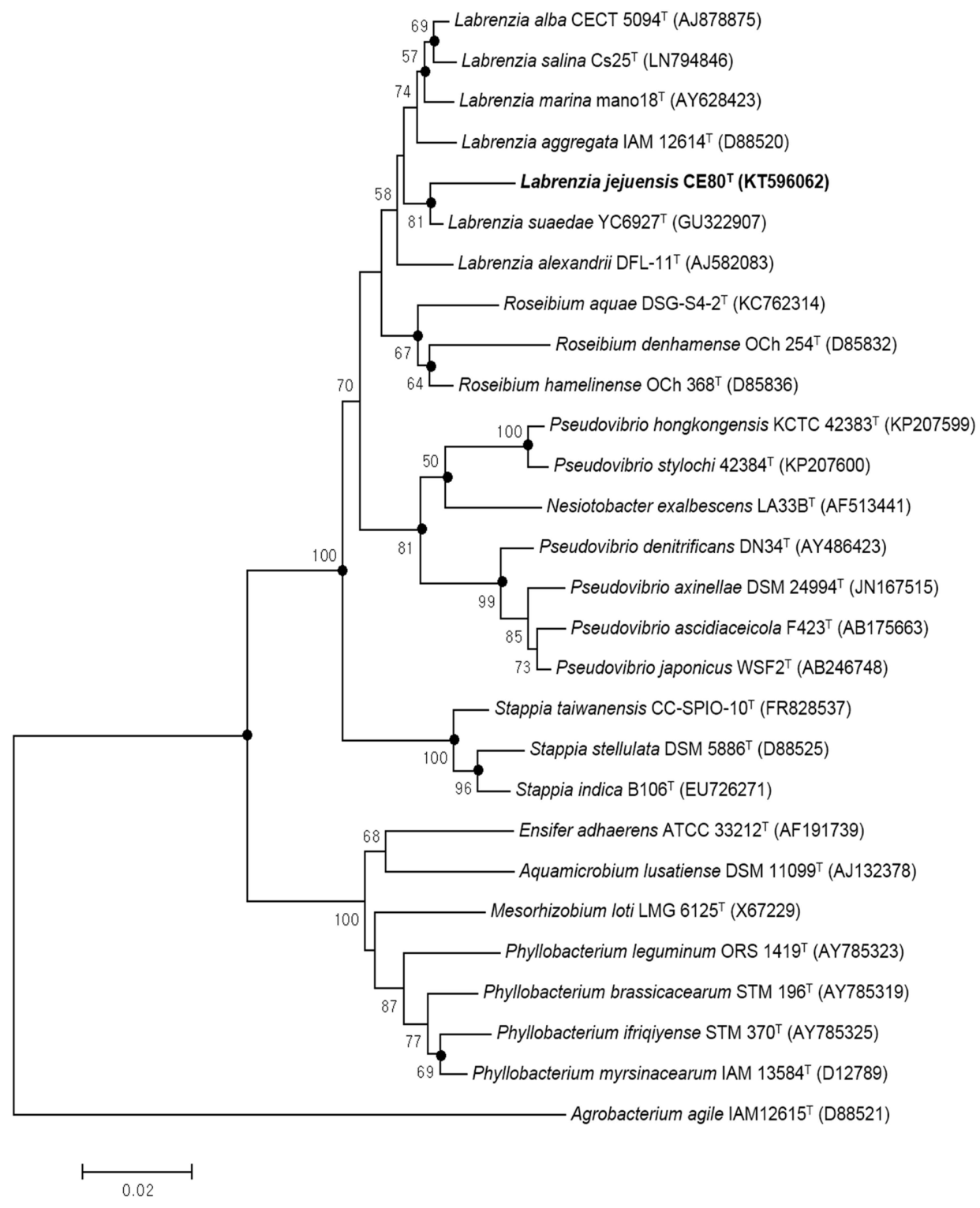

Fig. 1. Neighbour-joining phylogenetic tree, based on $16 \mathrm{~S}$ rRNA gene sequences, for strain $\mathrm{CE} 80^{\mathrm{T}}$ and genus Labrenzia.

Agrobacterium agile IAM $12615^{\mathrm{T}}$ (D88521) was used as an outgroup. Numbers at branch nodes are bootstrap percentages based on 1000 resamplings; only values greater than $50 \%$ are shown. Filled circles indicate branches found in phylogenetic consensus trees generated with the Maximum-Likelihood and Maximum-Parsimony method. Bar, 0.02 substitutions per nucleotide position. 
(SQDG) was known to be characteristic in species of Labrenzia, but L. suaedae lacked SQDG. Similarly, SQDG was detected in strain $\mathrm{CE} 80^{\mathrm{T}}$ in this study.

The DNA G+C content of strain CE80 ${ }^{\mathrm{T}}$ was calculated as $55.9 \mathrm{~mol} \%$, which is lower than the defined range values (58-63 $\mathrm{mol} \%$ ) reported for members of the genus Labrenzia $[1,2,3,8,9]$. The DNA-DNA hybridization value between strain $\mathrm{CE} 80^{\mathrm{T}}$ and type strain L. suaedae was $56.1 \pm 2.8$. This value was less than the $70 \%$ threshold value recommended for the delineation genomic species of novel strains by Wayne et al. [30]. Based on the results of phylogenetic, phenotypic, biochemical and chemotaxonomic analyses, strain $C E 80^{\mathrm{T}}$ represents a novel species of the genus Labrenzia, for which the name Labrenzia callyspongiae sp. nov., is proposed.

\section{Description of Labrenzia callysponigae sp. nov.}

Labrenzia callyspongiae (cal.ly.spon'gi.ae. N.L. gen. n. callyspongiae of the sponge Callyspongia).

Strain $\mathrm{CE}^{\mathrm{T}}{ }^{\mathrm{T}}$ is gram-negative, aerobic, and exhibited gliding motility. The organisms were light-brown, rodshaped, approximately 0.56-0.74 $\mu \mathrm{m}$ wide and 1.51-2.69 $\mu \mathrm{m}$ long and translucent after 3 days of incubation at $25^{\circ} \mathrm{C}$ on marine agar. Growth occurs at $10-37^{\circ} \mathrm{C}$ (the optimum temperature is $25^{\circ} \mathrm{C}$ ), $\mathrm{pH} 5.0-11.0$ (the optimum $\mathrm{pH}$ is 7.5) and in the $1-5 \%$ of $\mathrm{NaCl}(\mathrm{w} / \mathrm{v})$ (optimum at $1-3 \%, \mathrm{w} / \mathrm{v}$ ), respectively. The catalase and oxidase tests were positive. Nitrate reduced to nitrite. The strains also tested positive for hydrolysis of gelatin, Tween 80, urea and DNA but starch, casein, cellulose, aesculin, Tween 20, 40 and 60 tested negative. In the $20 \mathrm{NE}$ tests, a positive result showed for assimilation of $\beta$-galactosidase, but indole production, glucose fermentation, arginine dihydrolase, assimilated of D-glucose, D-arabinose, D-mannose, D-mannitol, N-acetylD-glucosamine, D-maltose, gluconate, caprate, adipate malate, citrate and phenylacetate tested negative. In the ZYM tests, alkaline phosphatase, esterase (C4), esterase lipase (C8), leucinearylamidase, valinearylamidse, cysteine arylamidase, trypsin, acid phosphatase, naphtol-AS-BIphosphohydrolase, $\alpha$-galactosidase were present, but lipase (C14), $\alpha$-chymotrypsin, $\beta$-glucuronidase, $\alpha$-glucosidase, $\beta$-glucosidase, $\mathrm{N}$-acetyl- $\beta$-glucosamidase, $\alpha$-mannosidase and $\alpha$-fucosidase were absent. The main fatty acids of strain $\mathrm{CE} 80^{\mathrm{T}}$ are $\mathrm{C}_{18: 1} \omega 7 c$, and summed feature 2 . The polar lipids profile showed presence of diphosphatidylglycerol, phosphatidylcholine, phosphatidylethanolamine, phosphatidylglycerol, phosphatidylmono-methylethanolamin, one unidentified aminolipid, one phospholipid and four unidentified lipids. The major respiratory lipoquinone was ubiquinone $10(\mathrm{Q}-10)$ and the DNA G+C content was $55.9 \mathrm{~mol} \%$.

The type strain CE80 ${ }^{\mathrm{T}}\left(=\mathrm{KCTC} 42849^{\mathrm{T}}=\mathrm{JCM} 31309^{\mathrm{T}}\right.$ ) was isolated from marine sponge Callyspongia elegans in Jeju Island, Republic of Korea.

\section{GenBank Accession Number}

The GenBank/EMBL/DDBJ accession numbers for the $16 \mathrm{~S}$ rRNA gene sequence and whole genome sequence of Labrenzia callyspongiae CE80 ${ }^{\mathrm{T}}$ are KT596062 and WAJT00000000.

\section{Acknowledgements}

This research was supported by the Leading Human Resource Training Program of Regional Neo Industry through the National Research Foundation of Korea (NRF) funded by the Ministry of Science, ICT and Future Planning (2016H1D5A1911152 \& 2017R1A2B4005688).

\section{Conflicts of Interest}

The authors have no financial conflicts of interest to declare.

\section{References}

1. Biebl H, Pukall R, Lünsdorf H, Schulz S, Allgaier M, Tindall $\mathrm{BJ}$, et al. 2007. Description of Labrenzia alexandrii gen. nov., sp. nov., a novel alphaproteobacterium containing bacteriochlorophyll $a$, and a proposal for reclassification of Stappia aggregata as Labrenzia aggregata comb. nov., of Stappia marina as Labrenzia marina comb. nov., and of Stappia alba as Labrenzia alba comb. nov., and emended descriptions of the genera Pannonibacter, Stappia and Roseibium, and of the species Roseibium denhamense and Roseibium hamelinense. Int. J. Syst. Evol. Microbiol. 57: 1095-1107.

2. Bibi F, Jeong JH, Chung EJ, Jeon CO, Chung YR. 2014. Labrenzia suaedae sp. nov., a marine bacterium isolated from a halophyte, and emended description of the genus Labrenzia. Int. J. Syst. Evol. Microbiol. 64: 1116-1122.

3. Camacho M, Redondo-Gómez S, Rodríguez-Llorente I, Rohde M, Spröer C, Schumann P, et al. 2016. Labrenzia salina sp. nov., isolated from the rhizosphere of the halophyte Arthrocnemum macrostachyum. Int. J. Syst. Evol. Microbiol. 66: 5173-5180.

4. Stapp C, Knösel D. 1954. Zur Genetik sternbildender Bakterien. Zentralbl Bakteriol Parasitenkd Infektionskr Hyg Abt 2. 108: 243-259 (in German).

5. Rüger HJ, Höfle MG. 1992. Marine star-shaped-aggregateforming bacteria: Agrobacterium atlanticum sp. nov.; 
Agrobacterium meteori sp. nov.; Agrobacterium ferrugineum sp. nov., nom. rev.; Agrobacterium gelatinovorum sp. nov., nom. rev.; and Agrobacterium stellulatum sp. nov., nom. rev. Int. J. Syst. Bacteriol. 42: 133-143.

6. Ahrens R. 1968. Taxonomische Untersuchungen a sternbildenden Agrobacterium-Arten aus der westlichen Ostsee. Kiel Meeresforsch. 24: 147-173 (in German).

7. Uchino Y, Hirata A, Yokota A, Sugiyama J. 1998. Reclassification of marine Agrobacterium species: proposals of Stappia stellulata gen. nov., comb. nov., Stappia aggregata sp. nov., nom. rev., Ruegeria atlantica gen. nov., comb. nov., Ruegeria gelatinovora comb. nov., Ruegeria algicola comb. nov., and Ahrensia kieliense gen. nov., sp. nov., nom. rev. J. Gen. Appl. Microbiol. 44: 201-210.

8. Pujalte MJ, Macián MC, Arahal DR, Garay E. 2005. Stappia alba sp. nov., isolated from Mediterranean oysters. Syst. Appl. Microbiol. 28: 672-678.

9. Kim BC, Park JR, Bae JW, Rhee SK, Kim KH, Oh JW, et al. 2006. Stappia marina sp. nov., a marine bacterium isolated from the Yellow Sea. Int. J. Syst. Evol. Microbiol. 56: 75-79.

10. Weisburg WG, Barns SM, Pelletier DA, Lane DJ. 1991. 16S ribosomal DNA amplification for phylogenetic study. J. Bacteriol. 173: 697-703.

11. Wilson K. 1987. Preparation of genomic DNA from bacteria. In current protocols in molecular biology.

12. Yoon SH, Ha SM, Kwon SJ, Lim J, Kim Y, Seo H, et al. 2017. Introducing EzBioCloud: a taxonomically united database of $16 S$ rRNA gene sequences and whole-genome. Int. J. Syst. Evol. Microbiol. 67: 1613-1617.

13. Thompson JD, Gibson TJ, Plewniak F, Jeanmougin F, Higgins DG. 1997. The CLUSTAL_X windows interface: flexible strategies for multiple sequence alignment aided by quality analysis tools. Nucleic Acids Res. 25: 4876-4882.

14. Hall TA. 1999. BioEdit: a user-friendly biological sequence alignment editor and analysis program for Windows 95/98/ NT. Nucleic Acids Symp Ser. 41: 95-98.

15. Tamura K, Stecher G, Peterson D, Filipski A, Kumar S. 2013. MEGA6: Molecular evolutionary genetics analysis version 6.0. Mol. Biol. Evol. 30: 2725-2729.

16. Felsenstein J. 1981. Evolutionary trees from DNA sequences: a maximum-likelihood approach. J. Mol. Evol. 17: 368-376.

17. Kluge AG, Farris FS. 1969. Quantitative phyletics and the evolution of anurans. Syst. Zool. 18: 1-32.
18. Saitou N, Nei M. 1987. The neighbor-joining method: a new method for reconstructing phylogenetic trees. Mol. Biol. Evol. 4: 406-425.

19. Felsenstein J. 1985. Confidence limits on phylogenies: an approach using the bootstrap. Evolution 39: 783-791.

20. Bankevich A, Nurk S, Antipov D, Gurevich AA, Dvorkin M, Kulikov AS, et al. 2012. SPAdes: a new genome assembly algorithm and its applications to single-cell sequencing. $J$. Comput. Biol. 19: 455-477.

21. Yoon SH, Lim JM, Kwon SJ, Chun J. 2017. A large-scale evaluation of algorithms to calculate average nucleotide identity. Antonie van Leeuwenhoek 110: 1281-1286.

22. Schaal, KP. 1986. Genus Acinomyces Harz 1877, 133AL. In Bergey's Manual of Systematic Bacteriology, vol. 2, pp. 1383-1418. Edited by P. H. A. Sneath, N. S. Mair, M. E. Sharpe \& J. G. Holt. Baltimore; Williams \& Wilkins.

23. Cowan ST, Steel KJ. 1965. Manual for the Identification of Medical Bacteria. Cambridge University Press: London.

24. Sasser M. 1990. Identification of bacteria by gas chromatography of cellular fatty acids, MIDI Technical Note 101: MIDI Inc.

25. Minnikin DE, O'Donnell AG, Goodfellow M, Alderson G, Athalye M, Schaal A, et al. 1984. An integrated procedure for the extraction of bacterial isoprenoid quinones and polar lipids. J. Microbiol. Methods 2: 233-241.

26. Komagata K, Suzuki K. 1987. Lipids and cell-wall analysis in bacterial systematics. Methods Microbiol. 19: 161-207.

27. Tamaoka J, Komagata K. 1984. Determination of DNA base composition by reverse-phase high-performance liquid chromatography. FEMS Microbiol. Lett. 25: 125-128.

28. Ezaki T, Hashimoto Y, Yabuuchi E. 1989. Fluorometric deoxyribonucleic acid deoxyribonucleic acid hybridization in microdilution wells as an alternative to membrane filter hybridization in which radioisotopes are used to determine genetic relatedness among bacterial strains. Int. J. Syst. Bacteriol. 39: 224-229.

29. Richter M, Rosselló-Móra R. 2009. Shifting the genomic gold standard for the prokaryotic species definition. Proc. Natl. Acad. Sci. USA 106: 19126-19131.

30. Wayne LG, Brenner DJ, Colwell RR, Grimont PAD, Kandler O, Moore LH, et al. 1987. International committee on systematic bacteriology. Report of the ad hoc committee on reconciliation of approaches to bacterial systematics. Int. J. Syst. Bacteriol. 37: 463-464. 